\title{
Coming to Financial Close in PPPs: Identifying Critical Factors in the Case of Toll Road Projects in Indonesia
}

Public Works Management \& Policy

$1-29$

(C) The Author(s) 2020

Article reuse guidelines: sagepub.com/journals-permissions DOI: I0.1।77/1087724X209|4627 journals.sagepub.com/home/pwm

@SAGE

\section{Kei Endo',2 ${ }^{1 D}$, Alberto Gianoli², and Jurian Edelenbos ${ }^{2}$}

\begin{abstract}
In Indonesia, public-private partnerships (PPPs) schemes have been attracting a lot of attention to meet the huge demand for infrastructure developments. However, their applications are still limited and the financial close of a project tends to be behind the planned schedule. This research therefore aims to investigate the critical success factors (CSFs) causing fast/slow progress in the processes toward the financial close of PPPs toll road projects in Indonesia. The results revealed that, to realize smoother delivery of PPPs toll road projects in Indonesia to the financial close in the future, it is important to improve coordination among the related stakeholders especially between the central and local governments, though the other CSFs are currently well developed. The research also found an issue that should be addressed from a sustainability viewpoint, namely that the government highly depends on state-owned companies (SOEs) for a timely financial close of PPPs toll road projects.
\end{abstract}

\section{Keywords}

public-private partnerships, critical success factors, financial close, toll roads, Indonesia

\section{Introduction}

Public-private partnerships (PPPs) have gained a lot of popularity in realizing infrastructure projects across the world since the private finance initiative (PFI) was proposed by John Major's Conservative government in 1992 (Hodge et al., 2018). PPPs

'Japan International Cooperation Agency, Tokyo, Japan

${ }^{2}$ Erasmus University Rotterdam, Netherlands

\section{Corresponding Author:}

Kei Endo, Japan International Cooperation Agency, 5-25, Niban-cho, Chiyoda-ku, Tokyo 102-80 I2, Japan.

Email: endo.kei@jica.go.jp 
can be defined as a long-term cooperation between the public and private sectors for provision of infrastructure and services by sharing risks, costs, and profits (Hodge \& Greve, 2007; Klijn \& Teisman, 2003; Koppenjan, 2005). PPPs can be categorized into two models: the concession model and the alliance model (organizational cooperation partnership model) (Hodge \& Greve, 2007; Klijn et al., 2007; Klijn \& Teisman, 2000). The former is a model whereby the public contracts out some tasks/responsibilities of the project(s) to the private sector. There are various types of private sector roles and responsibilities within the contract, such as build-operate-transfer (BOT), buildtransfer-operate (BTO), and design-build-finance-operate (DBFO) (Koppenjan, 2005; Weber et al., 2010; Yescombe, 2007). The latter model is a joint corporation established by both public and private parties in order to develop, maintain, and/or operate the infrastructure facility (Klijn \& Teisman, 2000; Koppenjan, 2005). Regardless of the type of model, PPPs are considered as sophisticated schemes making a project more innovative, more efficient, on-time, and on-budget than traditional infrastructure provision arrangements; moreover, they reduce pressure on government budgets by utilizing private funds, and this is why PPPs attract governments throughout the world (Hodge et al., 2018; Hodge \& Greve, 2007; Klijn et al., 2007; Steijn et al., 2011).

According to Hodge and Greve (2017), there have been four periods of growth of PPPs, which are recent world phenomena after PFIs were developed. The first period was between 1992 and 2001 when the PPPs concept was introduced and PPPs projects were realized in the United Kingdom and Australia. During the second period, from 2002 to 2007, PPPs spread to many other countries such as Canada, France, and Spain. From 2008 to 2012, in the third period, the PPPs boom faced a downturn due to the global financial crisis; governments needed to rescue their PPPs projects from bankruptcy rather than establishing new PPPs projects. As the global economy recovered from the 2008 financial crisis, PPPs were slowly rekindled in the countries with an old PPPs history, and simultaneously they began to boom in the United States and developing countries. This is the fourth period. In developing countries, PPPs have been preferred to reduce the problem of public sector budget constraints (Asian Development Bank [ADB], 2017a; McKinsey Global Institute, 2016; Organisation for Economic Co-operation and Development [OECD], 2012).

Through the past decades, PPPs have matured and have become major financial schemes in many developed countries (Osei-Kyei \& Chan, 2017a). On the other hand, in developing countries, the number of realized PPPs projects is still limited though a certain level of private funds has been utilized for energy and information and communications technology (ICT) sectors that are not regarded as PPPs but as privatization (Engel et al., 2014). The ADB (2017b) pointed out that only energy and information and communications technology (ICT) sectors share in the majority of projects using private funds in almost all of the Asian developing countries. Moreover, in developing countries, many PPPs candidate projects were postponed/delayed during the processes toward the financial close and, at worst, canceled (Babatunde \& Perera, 2017). This might be because developing countries do not have well-developed PPPs modalities or sufficient government support facilities compared to developed countries (ADB, 2017b; Babatunde \& Perera, 2017). Also, risk allocation methods may be the reason that the 
private sector does not eagerly participate in PPPs projects; developing countries generally tend to impose demand risk on the private sector (Aziz, 2007; Osei-Kyei \& Chan, 2017a) while with availability/service-based PPPs the public sector bear the demand risk (Weber et al., 2010; Yescombe, 2007) which is generally applied in developed countries such as the United Kingdom, Australia, and Hong Kong. However, the reason that PPPs projects have not yet been identified well and tend to be postponed/delayed during the processes toward the financial close in developing countries is still a mystery since there have not been many comprehensive research projects on PPPs, especially regarding the success factors of PPPs projects in developing countries excluding China (see Chan et al., 2010; Ke et al., 2010, for example, regarding research on PPPs in China). Moreover, few researches have reported comprehensive information about PPPs in developing countries; this could probably be due to the short history of PPPs and there being less academic scholars in the field in developing countries.

This article, therefore, is a first step to deepen the understanding of the current situation of PPPs in developing countries, or the situation that many PPPs projects have not yet been developed well, focusing on PPPs in Indonesia, which is one of the most advanced countries in PPPs framework and adoption in South East Asia. In particular, this research aims at identifying critical factors for timely project development to the financial close by applying the theory of critical success factors (CSFs) of PPPs projects to real PPPs projects (case projects) in Indonesia as explained in the following sections. It is expected that this research will offer academic insights into actual PPPs schemes and contribute to the further mobilization of PPPs schemes in developing countries.

Followed by this introduction section, this article has the following structure: outline of PPPs in Indonesia (Section 2); objective of research (Section 3); theory of CSFs of PPPs projects that is utilized as basic concept for the research (Section 4); research design and methodology (Section 5); and result, discussion, and conclusion (Sections 6,7 , and 8 , respectively).

\section{PPPs in Indonesia}

Indonesia is among the developing countries exploring PPPs schemes. It is regarded as having the biggest infrastructure investment gap among the G20's countries (McKinsey Global Institute, 2016). The huge demand for infrastructure development and the accompanying shortage of financial resources has become one of the pressing issues in the country and is being treated as a political priority topic. According to the Ministry of National Development and Planning, the demand for infrastructure between 2015 and 2019 was approximately 369 billion USD for projects such as roads, transport, and electricity. The available central and local governments' funds are approximately 152 billion USD, which is $41 \%$ of the total demand (Committee for Acceleration of Priority Infrastructure Delivery, 2017; Ministry of National Development Planning [BAPPENAS], 2014). The government of Indonesia, as is the trend for financing infrastructure projects across the other developing countries, planned to fill the investment gap of 59\% mainly with PPPs schemes totaling 135 
billion USD, along with mobilizing the funds of state-owned enterprises (SOEs) 82 billion USD, which would meet $37 \%$ and $22 \%$ of the demand, respectively (Committee for Acceleration of Priority Infrastructure Delivery, 2017).

To meet the financial demand by mobilizing private funds, the government recently introduced a policy to utilize the PPPs schemes. Presidential Regulation No. 67 of 2005 regarding Public Private Partnership in Infrastructure, replacement of Presidential Degree No. 7 of 1998 (the first formal PPPs regulation), was issued in 2005 to accelerate application of PPPs schemes by the first Yudhoyono administration (2005-2009). Under the following administrations, namely the second Yudhoyono administration (2009-2014) and the Joko administration (2014-present), led by the president's initiative, PPPs regulation and support facilities in Indonesia were well developed during a relatively short period of time. There have been many examples of state-owned financial institutes established; in 2009, Sarana multi infrastructure (SMI) which is dedicated to providing finance and feasibility studies to infrastructure projects was established; in 2009 the Indonesia Infrastructure Guarantee Fund (IIGF) was established; in 2014 a PPPs unit in charge of PPPs project preparation, including evaluation and approval of government support, was established; in 2012 the Government introduced the Viability Gap Funding (VGF) which is financial support scheme and in 2015 the availability payment (AP) scheme which is a return on investment method with government budget instead of tariff; in 2009 the PPPs book which officially makes note of all of the PPPs projects in Indonesia was established (Committee for Acceleration of Priority Infrastructure Delivery, 2017; OECD, 2012). As a result, compared with other developing countries in the ASEAN (Association of Southeast Asian Nations) region, Indonesia is now regarded as one of the most highly developed countries in terms of environment for developing PPPs projects, together with the Philippines, Thailand, and Vietnam (ADB, 2017b; United Nations Economic and Social Commission for Asia and the Pacific [UNESCAP], 2017).

Despite a relatively well-established PPPs environment with the various arrangements of PPPs support facilities and regulations, it is difficult to say that PPPs in Indonesia have been successful, to date, in terms of the number of projects which have been financially closed and the time spent from project planning to financial close. As of November 2017, only 12 projects, including one water supply project, one ICT project, and one power plant project have been financially closed since the new PPPs regulations (the Presidential Regulation No. 38 of 2015) were introduced by the Joko administration (PT Sarana Multi Infrastruktur [SMI], 2017). Not all of the projects that were financially closed and the projects that were tendered went smoothly (e.g., the Umbulan Water Supply project (PT SMI, 2017) and the Central Java Power Plant project [OECD, 2012].

\section{Objective of Research}

Considering the situation that many PPPs projects have not yet been developed well in Indonesia, which is a problem other countries have also been facing, it is important to review how well the existing PPPs schemes work and analyze why these problems occur to be able to apply the results in further PPPs schemes in Indonesia. This, in turn, 
is the research objective. The reasons why only a few PPPs projects reach financial close are due to a problem of project identification and/or prolongation during the project formulation process from project planning to financial close. This research targets the latter reason due to the availability of the relevant information for analysis, although this article recognizes that the former reason is also of great importance and so should be investigated carefully to fully understand the situation. In other words, this research investigates the factors differentiating fast or slow progress in the processes toward the financial close of PPPs projects. It focuses on the various stages of the project up to the financial close; the project planning and preparation stages, in which necessary studies and discussions on the project have been conducted; the transaction (bidding) stage; and the stage for the winning bidder to investigate financial arrangements (Delmon, 2011; Grimsey \& Lewis, 2007; Kwak et al., 2009). It should be noted that the project implementation stage (after financial close) have been intentionally excluded from this research.

This research focuses specifically on the toll road sector because it is the most active and advanced sector for PPPs schemes in Indonesia and has the most projects that are either financially closed or under preparation compared with any other sectors. The main research question is therefore: "To what extent have the PPPs schemes for toll road infrastructure projects in Indonesia matured and which factors lead to fast or slow progress in the processes toward the financial close of these projects?"

\section{Theory of CSFs of PPPs Projects}

\section{History and Trend of Research on CSFs of PPPs Projects}

With the worldwide boom of PPPs projects and the various failures in terms of cost, time, and quality (Babatunde \& Perera, 2017; Kwak, 2002; Kwak et al., 2009; T. Liu et al., 2016; Pieters et al., 2014), a workable and efficient protocol for a successful project has been investigated. To identify the best ways of realizing PPPs projects successfully, researchers have tried to apply the concept of the CSFs to the PPPs schemes. It should be noted that the success of PPPs in the context of CSFs research has been defined from a contractual perspective such as construction period, quality, and costs (Flyvbjerg, 2017; Hodge \& Greve, 2017; Ke et al., 2013), though the success is able to be judged more broadly from the overall performance perspective such as the innovative and efficient character of the project (Klijn \& Koppenjan, 2016; Steijn et al., 2011).

In the 1970s, the CSF model was developed in the field of management studies (Babatunde et al., 2016; Chen, 1999; Jefferies et al., 2002; Mohr \& Spekman, 1994; Osei-Kyei \& Chan, 2015; Rochart, 1979) and defined as a limited number of crucial areas in which results will lead to favorable goals (Chen, 1999; Rochart, 1979, 1982). During the last couple of decades, when the PPPs concept started to grow (Li et al., 2005; Tang et al., 2010; H. Wang et al., 2019), research on CSFs became a major topic in PPPs studies (e.g., Ke et al., 2009; Osei-Kyei \& Chan, 2015; Tang et al., 2010): researchers conducted questionnaire surveys, case studies, and literature reviews, 
summarizing the CSFs for PPPs projects (e.g., Ameyaw et al., 2017; Jefferies et al., 2002; Kwak et al., 2009; Osei-Kyei \& Chan, 2015, 2017b; Tiong, 1996; X. Zhang, 2005a, 2005b, 2005c; W. R. Zhang et al., 1998).

So far, there are diverse studies on the CSFs for PPPs in terms of countries, sectors, and stages in the PPPs arrangements (Osei-Kyei \& Chan, 2015). Most studies on the topic have focused on China (e.g., Chan et al., 2010; Ng et al., 2012; Qiao et al., 2001), and several developed countries such as the United Kingdom and Australia (e.g., Akintoye et al., 2003; Bing et al., 2005; Jefferies et al., 2002; Li et al., 2005; Wilson et al., 2010), or general international cases (e.g., Kumaraswamy \& Morris, 2002; Tiong, 1996; X. Zhang, 2005a, 2005b, 2005c). Recently diverse studies have also been conducted in developing countries such as India, Malaysia, Ghana, Nigeria, and Tanzania (e.g., Ameyaw \& Chan, 2016; Ameyaw et al., 2017; Babatunde et al., 2016; Babatunde \& Perera, 2017; Gupta et al., 2013; Ismail, 2013; Kavishe \& Chileshe, 2018; Kwofie et al., 2016). The studies have been in various sectors, for example, the transport sector (e.g., Askar \& Gab-Allah, 2002; Zou et al., 2008); water sector (e.g., Ameyaw \& Chan, 2016; Meng et al., 2011); power sector (e.g., Ozdoganm \& Birgonul, 2000; Zhao et al., 2010); and housing sector (e.g., Abdul-Aziz \& Kassim, 2011; Kavishe \& Chileshe, 2018; Sengupta, 2005), though most research has dealt with general sectors (Ameyaw et al., 2017). There are also diverse studies on CSFs for different stages, such as the project planning stage and implementation stage (e.g., Ahmadabadi \& Heravi, 2019; Ameyaw et al., 2017; J. Liu et al., 2015; X. Zhang, 2005c).

\section{Literature Review on CSFs of PPPs Projects}

In this sub-section, the CSFs of PPPs projects have been broadly reviewed irrespective of their differences so that all of the possible factors affecting have been taken into account. Furthermore, the CSFs only related to project development processes from the planning stage to a financial close of the PPPs toll road projects were specifically selected for this research. It should be noted that the CSFs summarized here are not specific to a particular stage (planning/preparing/transaction stage) but apply to the entire processes from the planning stage to the financial close in accordance with previous studies (e.g., Osei-Kyei \& Chan, 2015). The following literature review covers studies on CSFs in general including developing countries such as Indonesia (e.g., Abednego \& Ogunlana, 2006; Chou \& Pramudawardhani, 2015; Wibowo \& Alfen, 2014, 2015) and specifically toll road projects (e.g., Ahmadabadi \& Heravi, 2019; Y. Wang, 2015).

CSFs related to fast/slow progress in the processes toward financial close of PPPs projects can be categorized into three groups: (a) appropriate government roles and responsibilities, (b) appropriate risk allocation between the public and private sectors, and (c) a sound financial arrangement. It should be noted that factors such as a strong and reliable private consortium (Almarri \& Boussabaine, 2017; Bing et al., 2005; Kavishe \& Chileshe, 2018; Zhao et al., 2010), social support (Jacobson \& Choi, 2008; Kwofie et al., 2016; $\mathrm{Ng}$ et al., 2012), and competitive and transparent procurement processes (Dulaimi et al., 2010; Kwofie et al., 2016; Li et al., 2005) that have been frequently noted in previous research have been excluded from the CSFs which have 
been utilized in this research, as they are the CSFs affecting the quality of construction works and operation or "value for money" of the project rather than speed leading to a financial close. Factors related to macroeconomic environments, which are also frequently identified as important CSFs, such as stable macroeconomic conditions (Chan et al., 2010; Osei-Kyei \& Chan, 2017b; X. Zhang, 2005b) and sound economic policies (Almarri \& Boussabaine, 2017; Babatunde et al., 2016; Cheung et al., 2012) have also been excluded as these are not different among the projects in Indonesia.

Appropriate government roles and responsibilities. The first group of CSFs to gain a timely financial close of PPPs projects is appropriate government roles and responsibilities. The government plays a critical role in developing PPPs infrastructure projects, since most PPPs projects are proposed by the government, and the ultimate responsibility for delivering a service is with the government. The number of CSFs related to the government's roles and responsibilities identified in previous research is the majority of the three groups. This group mainly consists of the following CSFs: (a) favorable legal and regulatory framework for conducting the PPPs project (Kwak et al., 2009; Kwofie et al., 2016; Li et al., 2005; T. Liu et al., 2016; Verhoest et al., 2015); (b) well-organized/coordinated government authorities, led by a Central Coordinating Government Authority (CCGA; sometimes referred as a PPPs unit), with clear demarcation of roles and responsibilities among government institutions for the project formulation processes from project preparation to financial close (Ameyaw \& Chan, 2016; Chan et al., 2010; Chou \& Pramudawardhani, 2015; Hurk et al., 2016; Wibowo \& Alfen, 2015; X. Zhang, 2005c); (3) providing a good PPPs candidate project in terms of both technical and financial aspects (Ismail, 2013; Li et al., 2005; T. Liu et al., 2016; Osei-Kyei \& Chan, 2017b; Tang \& Shen, 2013b); (4) strong political/ governmental commitment assuring the project companies a smooth implementation of the project (e.g., support for obtaining approvals, such as government financial support and land acquisition) (Ahmadabadi \& Heravi, 2019; Jacobson \& Choi, 2008; Osei-Kyei \& Chan, 2015; Wibowo \& Alfen, 2015; X. Zhang, 2005c).

Appropriate risk allocation between the public and the private sectors. The second group of CSFs is "appropriate risk allocation between the public and private sectors." There are a number of risks in the financial, technical, social, and environmental aspects, such as construction risk, revenue/demand risk, and land acquisition risk, within any infrastructure projects (Bing et al., 2005; Chou \& Pramudawardhani, 2015; Ke et al., 2010; Yescombe, 2007). Allocation of these risks is one of the most important factors for success of the tender because the private companies tend to hesitate to participate in the projects if there are too many risks and uncertainties (Ameyaw et al., 2017; H. Wang et al., 2019). Unfortunately, there is no clear answer to the appropriate risk allocation, since the risks and capability of the parties concerned vary between different projects, sectors, and countries; however, in general, it is recommended that risks should be allocated to the parties that can mitigate and manage them the best (Kwak et al., 2009; Osei-Kyei \& Chan, 2015; Roumboutsos \& Anagnostopoulos, 2008; X. Zhang, 2005c). In order to find the risks and realize the appropriate risk allocations, 
the following CSFs are included in the second group: (a) clear mechanism to decide risk allocation among the parties (Babatunde \& Perera, 2017; Cheung et al., 2012; Kavishe \& Chileshe, 2018; Osei-Kyei \& Chan, 2015; X. Zhang, 2005a); and (b) government/governmental agency guarantee for taking critical risks with clear administrative procedures (Ahmadabadi \& Heravi, 2019; Babatunde \& Perera, 2017; Osei-Kyei \& Chan, 2017a, 2017b; H. Wang et al., 2019; X. Zhang, 2005b).

Sound financial arrangements. The third group of CSFs is "sound financial arrangements." A well-defined financial arrangement is very important for PPPs projects since projects basically have to recover the project costs only by revenue from service users and the residual value of the project assets. There are various financial instruments, such as debt, equity, and mezzanine finance (Weber et al., 2010; Yescombe, 2007). Appropriate instruments and balances of them are critical for maximizing the financial efficiency of any project. To make the project financially feasible and encourage private investors to participate in the project, the following CSFs are essential: (a) mature and available financial market (Ameyaw \& Chan, 2016; Jefferies et al., 2002; $\mathrm{Ng}$ et al., 2012; Osei-Kyei \& Chan, 2017a; Zhao et al., 2010) that provides the project company with finance, especially long-term loans, fixed and low interest rate loans, standby facilities in case of revenue shortfalls or cash flow problems; (b) government financial support to make the project bankable (Ameyaw et al., 2017; Babatunde \& Perera, 2017; Kwak et al., 2009; H. Wang et al., 2019), such as a VGF scheme that gives financial support for the capital investment of the project, budget financing for the remuneration, such as (a) AP scheme; (b) shadow-toll payment scheme; (c) payment adjustment mechanism for stable revenue; and (d) Present Value of Revenues (PVRs) contract scheme that allow the extension of concession periods to recover the project cost in case the revenue is lower than expected (Engel et al., 2014; PublicPrivate Infrastructure Advisory Facility [PPIAF], 2017; Weber et al., 2010).

\section{Research Design and Methodology}

In this research, based on multiple case studies of PPPs toll road projects that successfully reached financial close fast, as well as the PPPs toll road projects that were/have been prolonged in financial close, important factors for the fast/slow progress in the processes toward financial close of the PPPs toll road projects are expected to be brought to light with high validity. Based on the literature review of CSFs for PPPs projects, (a) governmental roles and responsibilities, (b) risk allocation between the public and the private sectors, and (c) sound financial arrangements are utilized as independent variables (IVs) or factors influencing the dependent variables (DVs) that result in a fast/slow progress in the processes toward financial close of PPPs projects.

To conduct multiple case studies with high validity and reliability, all 11 solicited PPPs toll road projects mentioned in the PPPs book from 2018 and 2017 published by the Ministry of National Development Planning (BAPPENAS) were selected as case projects. Unsolicited projects proposed by private investors are excluded from the case projects. It should also be noted that Surabaya Madura Toll Road project and Tanjung 
Table I. Classification of the Case Projects.

\begin{tabular}{|c|c|c|}
\hline Name of group & $\begin{array}{l}\text { Name of project (time spent from } \\
\text { planning stage up to financial close) }\end{array}$ & Note \\
\hline $\begin{array}{l}\text { Fast Progress } \\
\text { Group }\end{array}$ & $\begin{array}{l}\text { PI: Batang-Semarang Toll Road } \\
\text { (<II months); P2: Probolinggo- } \\
\text { Banyuwangi Toll Road ( }<3 \text { I } \\
\text { months); P3: Serang-Panimbang } \\
\text { Toll Road (5I km) }(<3 \text { I months); } \\
\text { P4: Sukabumi Ciranjang Toll Road } \\
\text { (N/A) }\end{array}$ & $\begin{array}{l}\text { - These projects reached } \\
\text { financial close from the } \\
\text { planning stage within } 36 \\
\text { months. } \\
\text { - P4: No bidding but direct } \\
\text { appointment to SOE. } \\
\text { - Information references: PPPs } \\
\text { Book (from } 2012 \text { to } 2017 \text { ) } \\
\text { and project summary sheet } \\
\text { of BPJT. }\end{array}$ \\
\hline $\begin{array}{l}\text { Slow Progress } \\
\text { Group }\end{array}$ & $\begin{array}{l}\text { P5: Balikpapan-Samarinda Toll Road } \\
\text { (>50 months); P6: Cisumdawu Toll } \\
\text { Road (>58 months); P7: Manado- } \\
\text { Bitung Toll Road ( }>56 \text { months); } \\
\text { P8: Pandaan-Malang Toll Road (>56 } \\
\text { months); P9: Serang-Panimbang Toll } \\
\text { Road (33 km) (process ongoing); } \\
\text { PI0: Semarang-Demak Toll Road } \\
\text { (process ongoing); PI I: Yogya- } \\
\text { Bawen Toll Road (process ongoing) }\end{array}$ & $\begin{array}{l}\text { - P5 to P8 reached financial } \\
\text { close from the planning stage } \\
\text { over } 36 \text { months. } \\
\text { - } \text { P9 to PI I were in process } \\
\text { toward financial close but their } \\
\text { preparation was prolonged } \\
\text { (more than } 18 \text { months). } \\
\text { - Information references: PPPs } \\
\text { Book (from } 2012 \text { to } 2017 \text { ) } \\
\text { and project summary sheet of } \\
\text { BPJT. }\end{array}$ \\
\hline
\end{tabular}

Note. SOE = state-owned enterprises; PPPs = public-private partnerships; BPJT = badan pengatur jalan tol (Indonesia Toll Road Authority).

Priok Access Toll Road project are excluded from the cases because these projects are not a new BOT project but just an operation and maintenance (O\&M) contract of an existing toll road. The 11 case projects include various projects in different stages, including the projects that reached financial close and the projects that have been under preparation as well as the projects that were dropped from being candidate projects. To assess the relationship between the IVs and DVs based on the results of data collection, these projects were categorized into either "fast progress" group or "slow progress" group based on standard processing period defined in the PPPs book 2018: 36 months at maximum for all the processes toward financial close (planning, preparation, and transaction stages). This standard processing period is in line with previous studies too (e.g., Babatunde \& Perera, 2017). Therefore, in this research, "fast progress" project is defined as a project that reaches financial close from the planning stage within 36 months and "slow progress" project is defined as a project that exceeds this timeline. For the projects under preparation (before their finance close), we utilized standard processing periods for project preparation (studies) ( 8 months at maximum) defined in the PPPs book 2018 as a benchmark of fast/slow progress. Based on these criteria, the 11 case projects were classified into four "fast progress" group projects and seven "slow progress" group projects as shown in Table 1. 
In this research, data were collected through semi-structured interviews with key persons involved in PPPs projects from (a) Indonesia Toll Road Authority (BPJT), (b) BAPPENAS, (c) Coordination Ministry for Economic Affairs (CMEA), (d) The Committee for Acceleration of Priority Infrastructure Delivery (KPPIP), (e) Ministry of Finance (MoF), (f) PT Sarana Multi Infrastruktur (SMI), (g) PT Indonesia Infrastructure Finance (IIF), (h) PT IIGF, and (i) two Indonesian toll road companies. It is noted that only the interviewees and respondents who had a deep understanding and practical knowledge on PPPs projects in Indonesia were selected to obtain more accurate information. In addition to primary data through the interviews, secondary data was also acquired to supplement the information from the interviews as well as to heighten the validity and reliability of the primary information. The secondary data that was utilized included reports/documents issued by the government, governmental institutions, and private institution related to the PPPs projects such as toll road project summary documents from the BPJT and PPPs books from BAPPENAS.

Following the data collection, the similarities and differences of the IVs and those of the DVs among the case projects were compared, and the causal relationships between the IVs and DVs were analyzed in a qualitative manner.

\section{Result}

\section{Evaluation of Government Roles and Responsibilities}

Evaluation of favorable legal and regulatory framework for conducting the PPPs project: Sub-IV (I-I). Overall, the legal framework for PPPs projects has recently been developed with clarity and applied to the toll road sector. It was found that the Presidential Regulation No. 38 of 2015 is the basis on which all of the PPPs infrastructure projects in Indonesia and all of the ministerial regulations and detailed rules regarding PPPs projects have been developed. According to BAPPENAS and the MoF, the Ministerial Decree of National Development Planning No. 4 of 2015 regarding the operational guideline for the PPPs in Infrastructure Provision and Head of the National Procurement Agency (LKPP) Regulation No. 19 of 2015 regarding the guideline for the procurement of the business entity on PPPs in the infrastructure provision are the major legal basis for PPPs business processes along with the Presidential Regulation No. 38 of 2015. These regulations clearly and concretely define the necessary procedure to lead to financial close of PPPs projects in the planning, the preparation, and the transaction stages.

Moreover, it was apparent, through interviews with the BPJT and KPPIP, that improving the land acquisition procedure substantially contributed to the acceleration of the financial close of the projects that accompany land acquisition, since financial institutions normally require a certain level of land acquisition for the financial close in order to ensure project realization. Indonesian Law No. 2 of 2012 on Land Acquisition for Public Interest, the so-called New Land Acquisition Law, introduced a concrete procedure of land acquisition with a rigid time frame. The KPPIP also explained that based on the Ministry of Finance Regulation No. 219 of 2015 regarding 
state assets management, the State Asset Management Agency (BLU LMAN) was established to provide funding for land acquisition related to public works, especially toll road projects on behalf of the Government Contract Agency (GCA) (BPJT for toll road projects). Furthermore, to avoid the delay of the land acquisition process due to not enough funds in the BLU LMAN budget, Presidential Regulation No. 30 of 2015 regarding the Land Acquisition Implementation for Developing Public Facilities enabled private entities to pay land acquisition fees first, on the condition that they would be reimbursed by BLU LMAN after the completion of the land acquisition.

According to interviews with the BPJT and KPPIP, the Presidential Regulation No. 38 of 2015 also contributed to the acceleration of the tender process by separating it from land acquisition. Before the regulation, the tender was normally conducted after the land acquisition process reached a certain level (e.g., 50\% of the land acquisition needed to have been completed in one section for the project) otherwise the project had to wait for a long time until reaching financial close. However, after this regulation, the tender process is able to proceed once location determination of the necessary land is completed by the local government.

As mentioned above, the legal framework explained for realization of the PPPs infrastructure projects and land acquisition related to the PPPs projects has been well developed and applied to all of the case projects. According to the BPJT and KPPIP, the legal framework serves all of the projects well and no critical legal/regulation issue was observed in finding, appraising, and tendering the PPPs project during the research. However, old projects in 11 case projects, namely, P5, P7, and P8 were previously delayed in the project transaction stage due to prolonged land acquisition as there was no clear regulation about land acquisition and tender acceleration such as Law No. 2 of 2012 and the Presidential Regulation No. 38 of 2015.

Evaluation of well-organized/coordinated government authorities: Sub-IV (I-2). In the field of the PPPs infrastructure project in Indonesia, there are various stakeholders due to the complex nature of the PPPs schemes. According to interviews and the documents provided by the government, it is clearly understood that there are both CCGA and PPPs-related institutions dealing with PPPs projects in Indonesia and their roles and responsibilities are in general demarcated and coordinated well at the central government level in the PPPs toll road sector. This is because the sector is relatively mature compared with other sectors and because the BPJT and CCGA clearly understand which appropriate institutions are necessary to communicate with when formulating PPPs projects.

It is noted that there are a number of institutions that are involved in playing key roles led by the CCGA in Indonesia namely: CMEA, KPPIP, BAPPENAS, and the PPPs Joint Office. The PPPs Joint Office has played the role of CCGA since its establishment in 2016. However, it does not have a structural/formal system. It should also be noted that the PPPs unit of MoF is only involved when the project requires the financial support from the government. Therefore, in reality, the other formal ministries/ministerial institutions that are of a coordinating nature, such as the CMEA, KPPIP, and BAPPENAS, also play the role of the CCGA. 
According to interviews, these three institutions have relatively good demarcation and coordination between themselves. The BAPPENAS mainly takes care of the project screening and selecting stage (planning stage) whereas the CMEA focuses more on the implementation (construction) stage. The KPPIP is involved in all of the processes as a kind of leading coordinator because of its multi-institutional organization structure. The KPPIP's formal mandate on monitoring and debottlenecking is only for the priority projects; however, in practice, it also covers the national strategic projects at almost the same level as the priority projects. All the PPPs toll road projects in Indonesia have so far been categorized as either priority projects or national strategic projects, which means that all of the projects have been given support from the KPPIP. It is noted that the KPPIP, CMEA, and BAPPENAS play the role of coordinators, and it is the BPJT that carries all the processes themselves from planning to operation in principle. BPJT is a capable executing agency for toll road development because it has had experience with Build Operate Transfer (BOT) projects from 2005. Therefore, it can be understood that BPJT and KPPIP practically lead the recent PPPs toll road projects in Indonesia.

For all of the 11 case projects, demarcation and coordination among the central coordinating and the PPPs-related institutions can be evaluated as high level, that is, at the level of the central government. However, P10 was thought to have been delayed due to the lack of coordination/communication in the central government. According to the BPJT and KPPIP, the pre-qualification of the project had already begun in 2017; however, the process was suspended and it was decided that the project should be incorporated into a sea embankment project in Semarang City (which was a change in the project scope). It is deemed that this sudden scope change was due to the lack of communication inside the Ministry of Public Works and Housing (MPWH) or due to lack of communication with the political authority.

Compared to the high-level coordination and demarcation in the central government institutions, there is/was room for improving the coordination and demarcation between the central and local governments. According to interviews, in the 11 case projects, there were projects whose land acquisition processes were prolonged due to the lack of coordination between the central and local governments, namely: P5, P7, and P8. Moreover, there were also projects whose processes of studies were prolonged due to lengthy discussions between the central and the local governments: P6 and P11.

Evaluation of providing a good PPPs candidate project: Sub-IV (I-3). According to the LKPP Regulation No. 19 of 2015 and the Presidential Regulation No. 38 of 2015, PPPs projects are divided into the planning, preparation, transaction, and implementation stages. Prior to the transaction stage, several studies are conducted for formulating well-prepared and high-quality PPPs projects; preliminary study for confirming whether the PPPs project is eligible and the basic study conducted during the planning and preparation stages, respectively; the Outline Business Case (OBC) study, which is a so-called pre-feasibility study, consisting of studies of all of the aspects necessary for the project appraisal such as legal, technical, financial, risk management, and environmental and social aspects; and the Final Business Case (FBC) study, a so-called 
feasibility study that contains the information on the project necessary for the related ministries/institutions to approve it.

All of the PPPs toll road projects, including the 11 case projects, accumulated information (were studied); therefore, the candidate projects were expected to be wellprepared projects. However, from the interviews, it was apparent that some projects faced drastic changes within the technical and/or financial aspects during the preparation stages due to poor accumulation of information (studies) during previous stages. Based on the interviews, issues relating to the technical and/or financial design of the project were reported on P3, P6, and P9 even though these projects are/were listed in the PPPs book through the preliminary studies. Moreover, P4 was dropped from being PPPs candidate project due to a change in policy following the preliminary studies, though this consequence was regarded as inevitable or minor. It is noted that P11 was excluded from this category because its underlying problem was the coordination between the central and local governments rather than the poor quality of the study at the previous stage.

Evaluation of strong political/governmental commitment: Sub-IV (I-4). In Indonesia, all of the infrastructure projects are categorized according to their priority. First, infrastructure projects are divided into PRJMN (National Medium-Term Plan) 2015-2019 projects or non-PRJMN projects. In the PRJMN projects, 245 projects and two programs were selected as the National Strategic Project (PSN), and 37 projects were selected as priority projects within the President Regulation No. 3 of 2016 and No. 58 of 2017. The KPPIP categorizes the projects requested by the President/Vice President (socalled "top-down projects") and projects requested by the line ministries (so-called "bottom-up projects") based on criteria such as project size and economic impact. The PSN projects have diversity in terms of both the sector and the location, as reflected by the policy of "equal development among regions"; however, the toll road sector has the greatest number of projects (74 projects) within 17 infrastructure sectors.

The PSN projects, particularly the priority projects, can be understood as constituting a strong commitment on the part of the government. Based on the President Regulation No. 75 of 2014, the priority projects can obtain, due to their importance, special treatment from the KPPIP such as continuous monitoring of the progress and debottlenecking the issues by communicating with the related institutions if any; development/redevelopment of the OBC (pre-feasibility) study; determination of finance scheme; and assistance to accelerate a project realization. According to the KPPIP, it follows closely the status of both the priority projects and the PSN projects on a weekly/semi-weekly basis in order to keep up with the original schedule. The KPPIP also explained that its official mandate is only for the priority projects; however, it also covers all of the PSN projects in the toll road sector at the same level as the priority projects, although it cannot develop/redevelop the OBC (pre-feasibility) study for the PSN projects.

With regard to case projects, all 11 PPPs toll road projects are categorized into priority projects or PSN projects; the priority projects are the P2, P3, P5, P7, P9, and P11; the PSN projects are P1, P4, P6, P8, and P10. Therefore, all of the projects have been 
well monitored not only by the BPJT but also by the KPPIP. According to interviews with both the BPJT and KPPIP, the KPPIP provides support for the development of studies for some priority projects. One of these is the Environmental Impact Assessment (EIA) study for P9. Another is the OBC and EIA studies for P11. As mentioned earlier, the KPPIP cannot provide support for the development of studies for PSN projects. However, this is not deemed critical because, according to the BAPPENAS and MoF, the BPJT is normally able to conduct studies with its own budget as it has plenty of funding. Hence, the BPJT has never requested the support of the BAPPENAS and MoF for the development of studies.

\section{Evaluation of Risk Allocation Between the Public and Private Sectors: Sub-IV (2-I) and (2-2)}

The risk allocation between the public and the private sectors is discussed from the planning and preparation stages of the project and decided upon in the PPPs agreement. The PPPs projects that require a government guarantee, which is now standard in the toll road sector, have to follow the IIGF's Risk Allocation Guidelines prepared by the IIGF. The guidelines are based on a principle that risk should be allocated to the party best able to control it, in order to achieve the maximum value for money with the most efficient risk allocation. This supports the theory of risk allocation of the PPPs project suggested by a number of researches (e.g., Kwak et al., 2009; Osei-Kyei \& Chan, 2015; Roumboutsos \& Anagnostopoulos, 2008; X. Zhang, 2005c).

According to the guidelines, land acquisition risks which are one of the most problematic issues in project implementation, tariff adjustment risks, political risks (e.g., discriminatory changes in the law and delays in necessary approval), and government payment risks (e.g., disbursement of VGF and refund of the land bailout fund) should be covered by the public sector. Risks related to project implementation, such as design, construction, and commissioning risks, sponsor risks, financial risks, and operation risks should be essentially covered by the private sector. On the other hand, risks related to government tasks, such as network connectivity risks, interface risks, and political risks, should be covered by the public sector. It should be noted that demand risks are usually covered by the private sector in Indonesia except for the demand risks during a ramp-up period (first 5 years of the operation period) in a few projects, though there are different risk sharing models for the demand risks in toll road projects between countries (Engel et al., 2014; PPIAF, 2017; Weber et al., 2010).

In PPPs toll road projects in Indonesia, the risk allocation model suggested by the Risk Allocation Guidelines are generally utilized. According to the BPJT, BPJT has the basic risk allocation model (matrix) for the PPPs toll road projects completely in line with the IIGF's and shares it with the PPPs-related institutions. From interviews with various institutions, it was observed that the PPPs-related institutions, including the financial institutions, regard the BPJT's risk allocation model as a given (fixed) thing, which means there is no room for delay of determination on risk allocation due to prolonged discussions. 
In order to help realize the PPPs infrastructure projects, mitigating the risks of the projects and enabling banks to provide loans, a guarantee is provided to the projects by the IIGF. IIGF is a single window institution, established in 2009 and owned by the MoF, to provide the government guarantee for the PPPs infrastructure projects. It should be noted that only the risks covered by the public sector are generally covered by the IIGF's guarantee. According to the IIGF, co-guarantee with the MoF is provided in case the project costs are too great for the IIGF to cover the risks by themselves due to their limitations in their financial capability. According to the BPJT, as with the determination process of the risk allocation, that of the government guarantee is already also standardized through a series of toll projects, and there were/are no issues in the process so far.

When it comes to the 11 case projects, it can be understood that, based on the interviews with the BPJT, no issues occurred in the determination processes of both risk allocation and government guarantee. All the projects that reached the PPPs contract (P1 to P8 except P4 [direct assignment to the SOE]) utilized the government guarantee and were on schedule at their transaction processes, which involved the appraisal and discussion of risk allocation and the guarantee. This is because, as seen above, there is a clear risk allocation rule that the BPJT has to follow to utilize the IIGF's guarantee facility. To date, this still applies to cases in toll road projects in Indonesia, and an IIGF guarantee mitigates the project risks and enables banks to provide the required loans.

\section{Evaluation of Financial Arrangement}

Evaluation of mature and available financial market: Sub-IV (3-I). Infrastructure finance has been booming, and the government policy to accelerate infrastructure development by utilizing the PPPs schemes has only intensified the Indonesian financial market's appetite to finance PPPs infrastructure projects as long as the projects have profitability. SMI and IIF explained how the guarantee by the IIGF contributed to mitigating the financial institution's hesitation to invest in the PPPs projects. According to SMI, in Indonesia, there are a number of commercial banks available to finance the profitable infrastructure projects such as Bank Rakyat Indonesia (BRI), Bank Mandiri, Bank Central Asia (BCA), and Bank Negara Indonesia (BNI) and overseas foreign commercial banks are also available if some specific conditions are fulfilled. Moreover, there are also a number of development financial institutions available to finance infrastructure projects in Indonesia, such as the World Bank (WB) and the ADB. These development financial institutions are able to provide concessional loans, which offer a lower rate and longer repayment schemes than commercial banks, to realize unprofitable projects.

In addition to the above-mentioned financial institutions, there is a relatively new development financial institution now active in the PPPs infrastructure financial market, namely SMI. SMI is a SOE owned by the MoF. SMI was established in 2009 as a catalyst institution to accelerate infrastructure development; SMI is able to provide loans/investments in cases when the commercial banks have a limitation that prevents them from financing the project by themselves. Regarding the conditions of the loan, 
SMI can provide more concessional loans than the commercial banks (generally, SMI's grace period is up to 30 years while commercial banks' are generally 7-10 years, and its interest rate is 50-100 BP lower than the commercial banks) in case it does not crowd out the commercial banks from the market.

With regard to financing schemes in the toll road sector, it should be noted that the so-called semi-project finance scheme is utilized in Indonesia. According to SMI, none of the financial institutions in Indonesia, including SMI, can take the demand risks. Therefore, they provide loans on a basis of full-recourse project finance, which means the sponsors have an obligation to repay the loan in the case that the toll revenue is insufficient to repay the loan, which is different from a standard finance scheme for PPPs projects (non-recourse/limited-recourse project finance) which is often the case in other countries. The semi-project finance scheme contributes to an acceleration of the financial arrangement because the project does not need to rely only on its profitability to finance the project.

Another feature related to the finance aspect of toll road projects in Indonesia is the Contractor Pre-Finance (CPF) system. The CPF system was introduced to accelerate the projects implementation. Under the system, contractors can start construction works by utilizing their own funds and are reimbursed by the toll road company. The CPF system is very important in terms of speed of financial close, because the commercial banks tend to suspend financial close until the land acquisition process reaches a certain level. As for the CPF system, however, apprehension within the institutions also exists; BPJT explained that the CPF system is a relatively new system, and therefore nobody is sure at this moment whether the private toll road companies can acquire the finance (loans) from the banks in the future. In addition, there is another issue that enhances the possibility that the pure private companies may find it increasingly difficult to participate in the toll road projects, because the toll road companies and construction companies have to have enough financial capability to follow the CPF system.

As for the 11 case study PPPs toll road projects, P7 and P8 reached financial close with syndicate loans from the four biggest commercial banks in Indonesia (BRI, Bank Mandiri, BCA, and BNI) and SMI. According to BPJT, there was no delay caused by the loan agreements' conclusion after the concessionaire awarded these projects. BPJT explained that these projects are relatively profitable, and therefore it was easy for the toll road companies to acquire the loans since the banks did not have to worry about the toll road companies defaulting due to lack of revenues. SMI is involved in these projects and explained its participation as a catalyst to realize these projects; SMI's participation provided the projects with a kind of certification showing that the projects fulfill certain qualities, namely: financial, technical, and environmental. According to SMI, its participation as the equity investor like in P8 has a big positive impact for the financial institutions providing their loans. It is also understood that half of the projects (four projects namely P1, P2, P3, and P5 out of eight financially closed projects) applied the CPF system, which means that many PPPs toll road projects relied not on the finance structure of the project itself but on the CPF system for its financial close. 
Evaluation of government financial support: Sub-IV (3-2). In the Indonesian infrastructure sector, there are several government financial support schemes that have been introduced. First, VGF is the financial support for capital investment of a project and is available in the case that the estimated profit is not enough for the private company to implement the project. However, the VGF scheme has never been utilized and the supported BOT (S-BOT) scheme (BOT with government partial construction support) has been applied in the Indonesian toll road sector. BPJT explained that they do not want to utilize the VGF scheme because the VGF scheme takes a large amount of time to coordinate with the MOF and that the available amount of VGF tends to become lower than expected; the Umbulan Water Supply project took over 3 years to determine the VGF amount and the project's structure during the tender process (PT SMI, 2017), and the Bandar Lampung Water Supply project was suspended for approximately 5 years because no private company bid on it due to its low amount of VGF. The state-owned toll road companies also prefer the S-BOT scheme due to their suspicion against VGF's payment. Therefore, public and the private sectors currently agree to use the S-BOT scheme instead of the VGF scheme in the PPPs toll road sector. In the most recent S-BOT projects, including the case projects, due to MPWH policy that the state budget is utilized only for the non-toll roads, BPJT has utilized loans from the international/bilateral development financial institutions.

The second financial support is the AP scheme, in which the government pays a certain fee in exchange for toll road companies' services (construction, operation, and maintenance) instead of users' tariff, though the AP scheme is not strictly government financial support; in the Indonesian toll road sector, the AP scheme is usually regarded as one of the government financial support since the toll road company does not need to bear the demand/revenue risk that is one of the most serious risks for profitability. The AP scheme is excellent not only for the private sector but also for the public sector. From the public point of view, the BPJT can secure quality of the toll roads' construction, operation, and maintenance as the payment is provided only if the service requirement mentioned in the contract is fulfilled. However, despite these benefits, the AP scheme has never been utilized in the toll road projects in Indonesia. According to BPJT and MoF, the financial sources for AP have to be arranged by the MPWH (BPJT), yet this is again against MPWH policy that the state budget is utilized only for the nontoll roads; making it difficult to use in the toll road sector.

The third financial support is, though this is only for the toll road sectors, the IIGF's guarantee for the revenue during the ramp-up period (first 5 years of the operation period). This guarantee is applied only to the toll roads that have a revenue (traffic demand) that is difficult to predict. At the commencement of the project, this guarantee is helpful to maintain a certain level of cash flow.

Regarding the 11 case projects, $\mathrm{P} 5, \mathrm{P} 6, \mathrm{P} 7$, and $\mathrm{P} 9$ used the partial construction support (S-BOT scheme) and P1, P5, P7, and P8 obtained a guarantee for the revenue during the ramp-up period. These projects were originally less profitable and/or their revenue prediction (traffic volume) was difficult to estimate. According to BPJT and IIGF, there was no issue during structuring and tendering, because all of the necessary 
administrative procedures were already well developed. This applied to all of the projects, including the projects with the S-BOT scheme and the IIGF's guarantee.

\section{Discussion}

In this section, the findings of PPPs toll road sector in Indonesia have been carefully analyzed. First, based on the interviews and the documents, the evaluation of the IVs' actual situation in the 11 case projects have been summarized using the scale ( + : positive; 0 : neutral; -: negative) in Table 2 . It should be noted that of the term "N/A" is also within the table in IV 2 and IV 3, this is because the projects have not yet reached financial close (P10 and P11) or the project scheme was changed from an ordinary PPPs scheme (BOT with public tender bid) to a direct appointment to the SOE (P4). Table 2 shows that most of the IVs have a positive status in all or most projects, which means that the PPPs project's CSFs suggested by the previous researches are mostly fulfilled in the PPPs toll road projects in Indonesia. It is notable that four out of eight sub-IVs were perfectly achieved: political/government commitment (sub-IV 1-4); appropriate risk allocation between public and private (IV 2); financial market maturity and availability (sub-IV 3-1). It is difficult to closely analyze to what extent these IVs contributed to a timely financial close because there was no difference in the status of these IVs (homogeneous result) among the projects. However, considering the fact that the finance source of the project is an essential condition for financing the project and that risk mitigation of the project and political support ease the private companies' worry for joining the project, it is deemed that these IVs had a significant positive impact on a timely financial close.

In addition to sub-IV 1-4, IV 2, and sub-IV 3-1, government financial support (Sub-IV 3-2) also did not receive negative (-) status in any of the projects, but it has heterogeneous statuses of neutral $(0)$ and positive $(+)$. Comparing the statuses of Sub-IV 3-2 with the result of DV, it is observed that the projects with government financial support, positive $(+)$ status, have a tendency to be slow while the projects without government financial support (neutral [0] status) do not. This might be due to the fact that the projects with government financial support need a long discussion, for instance, on how much the financial support is necessary. However, our interview revealed that this was the case only in $\mathrm{P} 9$ and there was not such a report for the other projects; P3 and P9 were formerly one project planning to utilize the AP scheme to make the project bankable; however, the project was separated into two different projects to avoid prolongation of project preparation processes due to discussion on detail of the AP scheme, and only P3 was brought forward without government financial support to accelerate the project realization (even though it was a partial realization), leaving P9. As for the other projects with government financial support, the projects applied the S-BOT scheme and/or guarantee for the revenue during the ramp-up period, there was no delay caused by these supports as seen in the "Evaluation of government financial support: Sub-IV (3-2)" section. This means that the application of government financial support in a form of S-BOT and revenue guarantees, which is 


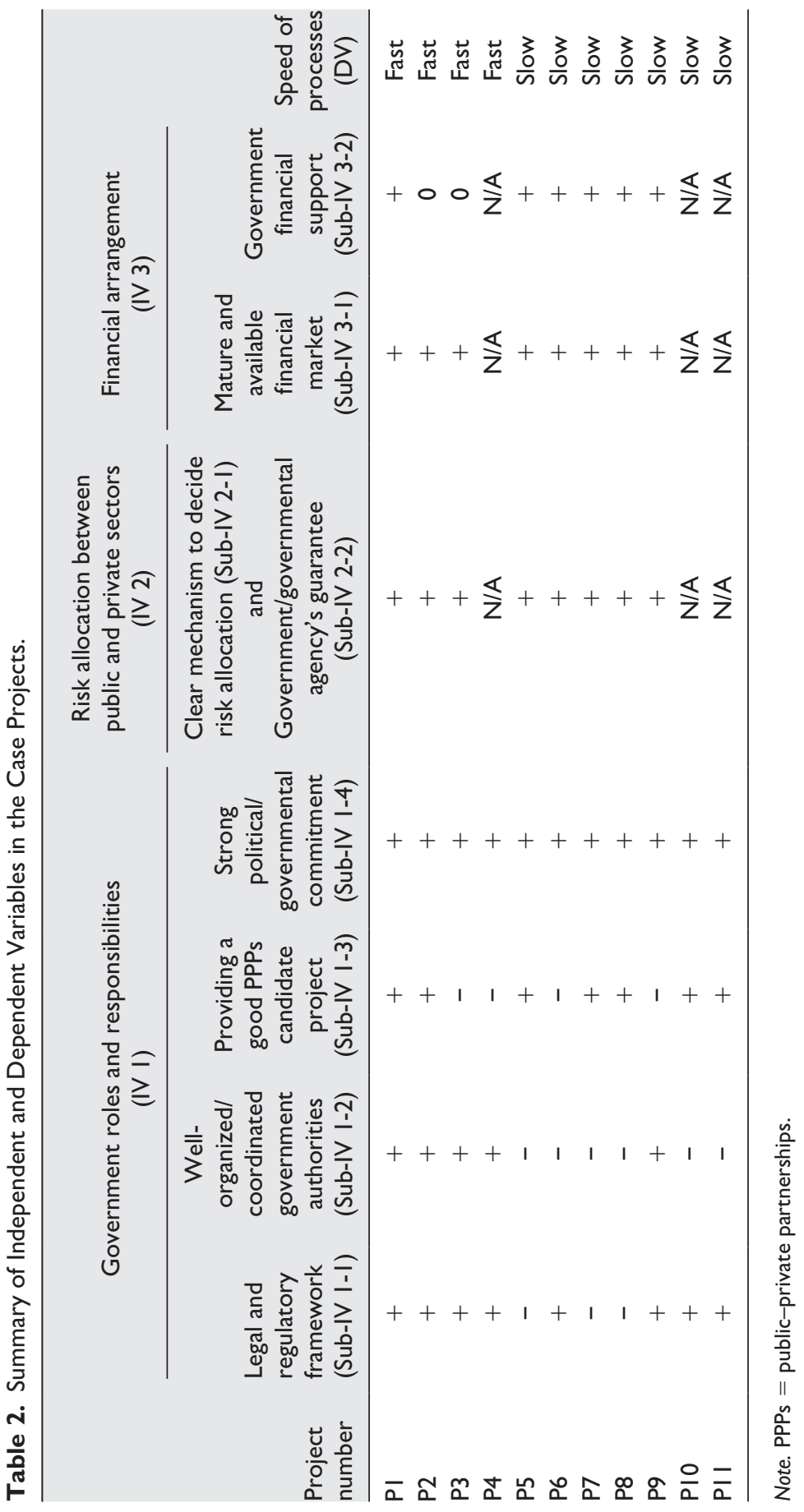


Table 3. Grouping of the Case Projects by Selected Independent Variables and Dependent Variables.

\begin{tabular}{|c|c|c|c|c|c|}
\hline $\begin{array}{l}\text { Project } \\
\text { group }\end{array}$ & $\begin{array}{l}\text { Project } \\
\text { number }\end{array}$ & $\begin{array}{l}\text { Legal and } \\
\text { regulatory } \\
\text { framework } \\
\text { (Sub-IV I-I) }\end{array}$ & $\begin{array}{c}\text { Well-organized/ } \\
\text { coordinated } \\
\text { government authorities } \\
\text { (Sub-IV I-2) }\end{array}$ & $\begin{array}{c}\text { Providing a good } \\
\text { PPPs candidate } \\
\text { project } \\
\text { (Sub-IV I-3) }\end{array}$ & $\begin{array}{l}\text { Speed of } \\
\text { processes } \\
\text { (DV) }\end{array}$ \\
\hline I & PI, P2 & + & + & + & Fast \\
\hline 2 & P3, P4 & + & + & - & Fast \\
\hline 3 & P9 & + & + & - & Slow \\
\hline 4 & PIO, PII & + & - & + & Slow \\
\hline 5 & P6 & + & - & - & Slow \\
\hline 6 & P5, P7, P8 & - & - & + & Slow \\
\hline
\end{tabular}

Note. PPPs = public-private partnerships.

currently the trend of development of PPPs toll road projects in Indonesia, does not have a negative effect on the speed of financial close.

As above, we confirmed that Sub-IV 1-4, IV 2, and Sub-IV 3-1 have a positive status $(+)$ in all of the projects (except "N/A" in some projects), and Sub-IV 3-2 did not affect the speed of financial close. However, despite these positive/neutral factors, seven out of 11 projects $(64 \%)$ were slow progress. This was apparently due to the other IVs' negative status: The legal and regulatory framework (Sub-IV 1-1), wellorganized/coordinated government authorities (Sub-IV 1-2), and provision of a good PPPs candidate project (Sub-IV 1-3). Therefore, the study focused on the correlation between the DV (fast or slow progress) and these three IVs to identify the determining factors. The case projects were analyzed as follows by summarizing them based on the status of the three Sub-IVs and DV as shown in Table 3, leaving out the other IVs without negative (-) status in the projects (Sub-IV 1-4, IV 2, and IV 3).

Group 1 (sub-IV 1-1: +; sub-IV 1-2: +; and sub-IV 1-3: +) (hereinafter described as " +++ ") and Group $2(++-)$ reached financial close fast while the other project groups were slow. This suggests that a positive status in all the sub-IVs was required for a timely financial close, with the exception of Group $2(++-)$, and that a positive status of sub-IV(s) cannot cancel the negative status even in one or two sub-IVs. Considering Group $2(++-)$ that reached financial close fast despite of the negative status in sub-IV 1-3, it is deemed that sub-IV 1-1 and 1-2 were more critical to a timely financial close than sub-IV 1-3. It can be understood that it is difficult to formulate the projects smoothly without a steadfast legal framework that the stakeholders can easily follow and good coordination among the government institutions to be able to make quick decisions regarding the project.

Regarding sub-IV 1-1 and 1-2, it is deemed that there is relationship between them. Group $6(--+)$ with a negative status in both Sub-IV 1-1 and 1-2 is composed of three projects, which account for $50 \%$ of all the projects that have a negative status in Sub-IV 1-2. In the case of projects in Group $6(--+)$, the lack of a legal and regulatory 
framework negatively affected coordination between the stakeholders, which led to prolongation in a financial close. Especially, during the land acquisition processes, these were prolonged because of the lack of coordination between the central and local governments which was caused by a lack of clear and concrete regulations about land acquisition and tender acceleration such as the Law No. 2 of 2012 and the Presidential Regulation No. 38 of 2015. Also, due to the lack of regulation and a setup of strong institutions that could coordinate the BPJT with other government institutions with regard to land acquisition, such as the KPPIP (established and activated in 2014) is another reason for the prolongation. However, it should be noted that there are now clear and concrete laws and regulations for the realization of PPPs projects, therefore there are currently much fewer projects categorized in Group $6(--+)$ than before.

Regarding other groups of projects with a negative status in Sub-IV 1-2, both Group $4(+-+)$ and Group $5(+--)$ show slow progress toward financial close. This suggests that having only a steadfast legal and regulatory framework (Sub-IV 1-1) is not sufficient for timely financial close, and Sub-IV 1-2 and/or Sub-IV 1-3 are also critical. Comparing Group $2(++-)$, Group $3(++-)$, and Group $4(+-+)$ has brought an interesting implication on this point. It is noted that there are results of both fast and slow progresses in case of the combination "++-"; that only Sub-IV 1-3 has a negative status (Group 2 and 3), while with combination " +-+ " that only Sub-IV 1-2 has a negative status (Group 4) leading to a slow financial close without exception. This suggests that the negative status in Sub 1-3 might be able to be compensated by the other positive statuses, especially by strong political/governmental leadership and quick and efficient coordination among the related authorities regarding the measures to be taken. Indeed, projects in Group 2 (P3 and P4) were accelerated by strong politi$\mathrm{cal} /$ governmental leadership and extra consideration was provided for these projects to realize the projects as soon as possible: P3 was separated from P9 due to an AP scheme financial problem and dealt with before P9 (P3 and P9 are formerly one project); and P4 was directly appointed to the concessionaire of the adjacent toll road project based on the President Regulation No. 38 of 2015. However, it should be noted that the negative status in Sub-IV 1-3 was not continually controlled; P9 (Group 3) could not help being stuck in the preparation stage (before the bid) due to change of financial structuring of the project from the original plan as mentioned earlier.

The importance of good coordination between the governments (Sub-IV 1-2) can also be confirmed by reviewing the reason for slow progress toward financial close in P6 and P11. P6 faced a drastic alignment change in the detailed design study due to the lack of quality in the first study that was done, which was made without a serious involvement in the design of the toll road by the local government. P11 faced prolonged discussions between the central and local governments regarding design and preservation of historical sites, which was because Indonesian King governing the region possesses strong political power in the local government and in turn the central government was unable to maneuver the discussion in favor of itself. These cases show that the projects were unable to move smoothly and unable to realize a financial close without intense cooperation among the stakeholders and with a common understanding for a quick project realization. 
In addition to the above findings, through data collection and analysis, regarding IV 2 and IV 3, potential and unexposed problems/risks in realizing PPPs toll road projects in Indonesia were also found; though these IVs currently have either a positive $(+)$ or neutral (0) status in all of the projects and they contribute to sound financial structuring of the projects. The problems/risks are part of the demand risks (revenue risks) taken by the government, form of the government financial support, and the CPF system. Under the current system of the IIGF's guarantee, demand risks are shouldered by the toll road companies. The government is not willing to apply the AP scheme, whereby it is expected to pay a certain fee to the project company because of the MPWH's policy to use its budget for non-toll road projects. Therefore, under the current framework, there is the risk that only traditional SOEs are able to absorb the demand risks as they have a huge capital and are thus able to participate in the project. Indeed, according to the interviews, SOEs won the bids for all of the case projects. This situation can be interpreted as the government relays on SOEs for development of PPPs toll road projects to avoid bearing the demand risks. Fortunately, this tactic currently works, however may not be sustainable in the future, considering the huge demand for new toll road projects as well as the financial capacity of the SOEs.

Regarding government financial support, the S-BOT scheme that the government provides some of the construction works with multilateral/bilateral financial development loans instead of the VGF scheme is currently applied to PPPs toll road projects in Indonesia to avoid time-consuming administration processes. However, the S-BOT schemes also have its limitations for its application because multilateral/bilateral financial institutions cannot always provide finance due to financial capacity and/or lending policy such as environmental safeguard policy. Therefore, the VGF scheme is essential to realize the PPPs toll road projects in the future instead of the S-BOT scheme. However, it is anticipated in this case that projects formulation process to their financial close will be more complicated and thus take a longer time due to the lack of experience with the VGF scheme as water supply projects faced significant delays in their financial close due to applying the VGF scheme (seen in the "Evaluation of government financial support: Sub-IV (3-2)" section).

The concern with using a CPF system is that the toll road companies may not be able to acquire any loans or may take a long time to acquire loans in the future, and the projects could remain stuck at the implementation stage, since the CPF system does not guarantee future financial arrangements but allows the contractors to commence construction works using their own funding to accelerate the project's implementation. Also, it is anticipated that application of the CPF system promotes PPPs not by the pure private sector but by the SOEs, because only the SOEs with huge capital can make an advance payment for construction of the toll road under the CPF system.

\section{Conclusion}

This research examined to what extent PPPs schemes for toll road infrastructure projects in Indonesia have matured and what factors led to fast or slow progress in the processes toward the financial close of the projects. As a result, it was revealed that 
PPPs schemes for toll road infrastructure projects in Indonesia are currently highly developed. Especially, legal and regulatory frameworks regarding the PPPs projects and land acquisition, sound mechanism regarding risk allocation of the projects, the CCGA leading the project-related institutions, and financial institutions making it possible to finance the PPPs projects highly contribute to a fast financial close of the toll road projects in Indonesia. This regulatory and institutional setup for the PPPs projects is the fruits of efforts of the government of Indonesia, and this shows that a suitable environment for the PPPs projects can be created with the government's leadership.

The research also discussed challenges necessary to improve a timelier financial close, and the main factors that currently cause prolongation in the processes toward the financial close of PPPs toll road projects in Indonesia: proper coordination among the related stakeholders especially between the central and local governments regarding project preparation. To address this issue, it is highly recommended for the institutions that are related to PPPs toll road projects in Indonesia to create a mechanism to heighten the coordination level between the central and local governments as they addressed the same coordination issues inside the central government.

The research also shed light on potential risks that may shake the foundation of current relatively fast financial close of PPPs toll road projects in Indonesia, though the risks have not yet come to the surface. The projects heavily rely on the SOEs with huge capital for their financial close in order to meet the government policy of speedy project realization. The tactic of the government for timely financial close through SOEs without the government's having to bear demand risks works well so far, thanks to the relatively profitable and politically important nature of the toll road projects in Indonesia. In addition, government support in a form of partial construction of the toll roads by utilizing loans from the other countries/development institutions (S-BOT scheme) also sustains this tactic. However, considering the fact that there are limitations of both financial capacity of SOEs and the loans from overseas for the S-BOT schemes, it becomes difficult for the toll road projects to reach financial close in this way in the future. Therefore, from a sustainability viewpoint, it is necessary to break away from the current PPPs model which is unique to the Indonesian toll road sector and pursue the PPPs model with enough government financial support that attracts private firms, which might take a longer time for financial close as this research suggests.

The findings from this research will hopefully be utilized by PPPs practitioners to work with PPPs schemes in a more timely and sustainable way in the Indonesian toll road sector. Moreover, the findings of this research offer important implications to the other sectors in the country too. In Indonesia, few PPPs projects reached financial close in other sectors despite of existence of legal and regulatory frameworks regarding the PPPs projects, sound mechanisms regarding risk allocation of the projects, and access to financial markets. Based on the results of this research, this could be explained by the lack of coordination among related actors even at the central level, though this hypothesis should be confirmed by future studies. The findings and suggestions of this research are also meaningful for the PPPs schemes in the other countries too, especially developing countries struggling to adopt the PPPs schemes for infrastructure development. For 
the countries intending to apply the PPPs schemes, based on this research it is recommended that the government leadership first prepare themselves with a favorable PPPs environment. For the countries where a PPPs environment has already been arranged to some extent, it is recommended for the government to consider various ways of utilizing private finance wisely and not having to rely on the SOEs.

To cope with the current issue of the Indonesian toll road sector, future research would include investigating good practices which are able to enhance communication for PPPs projects between central and local governments. In addition, to consider countermeasures against bottlenecks during project development, CSFs related to particular stages up to financial close (planning, preparation, and transaction stages) should be investigated since each stage has different characteristics. Future research should also look into CSFs for unsolicited PPP projects as these are of increasing relevance in relation to toll road development in Indonesia.

\section{Author's note}

Kei Endo is also affiliated to the Erasmus University Rotterdam.

\section{Declaration of Conflicting Interests}

The author(s) declared no potential conflicts of interest with respect to the research, authorship, and/or publication of this article.

\section{Funding}

The author(s) received no financial support for the research, authorship, and/or publication of this article.

\section{ORCID iD}

Kei Endo iD https://orcid.org/0000-0002-6058-4138

\section{References}

Abdul-Aziz, A. R., \& Kassim, P. S. J. (2011). Objectives, success and failure factors of housing public-private partnerships in Malaysia. Habitat International, 35, 150-157.

Abednego, M. P., \& Ogunlana, S. O. (2006). Good project governance for proper risk allocation in public-private partnerships in Indonesia. International Journal of Project Management, 24, 622-634.

Ahmadabadi, A. A., \& Heravi, G. (2019). The effect of critical success factors on project success in Public-Private Partnership projects: A case study of highway projects in Iran. Transport Policy, 73, 152-161.

Akintoye, A., Hardcastle, C., Beck, M., Chinyio, E., \& Asenova, D. (2003). Achieving best value in private finance initiative project procurement. Construction Management and Economics, 21, 461-470.

Almarri, K., \& Boussabaine, H. (2017). Interdependency of the critical success factors and ex-post performance indicators of PPP projects. Built Environment Project and Asset Management, 7, 546-556. 
Ameyaw, E. E., \& Chan, A. P. C. (2016). Critical success factors for public-private partnership in water supply projects. Facilities, 34, 124-160.

Ameyaw, E. E., Chan, A. P. C., \& Owusu-Manu, D. (2017). A survey of critical success factors for attracting private sector participation in water supply projects in developing countries. Journal of Facilities Management, 15, 35-61.

Asian Development Bank. (2017a). Meeting Asia's infrastructure needs. https://www.adb.org/ sites/default/files/publication/227496/special-report-infrastructure.pdf

Asian Development Bank. (2017b). Public-private partnership monitor. https://www.adb.org/ sites/default/files/publication/381681/ppp-monitor.pdf

Askar, M., \& Gab-Allah, A. (2002). Problems facing parties involved in build operate, and transport projects in Egypt. Journal of Management in Engineering, 18, 173-178.

Aziz, A. M. A. (2007). Successful delivery of public-private partnerships for infrastructure development. Journal of Construction Engineering and Management, 133, 918-931.

Babatunde, S. O., \& Perera, S. (2017). Analysis of financial close delay in PPP infrastructure projects in developing countries. Benchmarking: An International Journal, 24, 1690-1708.

Babatunde, S. O., Perera, S., Zhou, L., \& Udeaja, C. (2016). Stakeholder perceptions on critical success factors for public-private partnership projects in Nigeria. Built Environment Project and Asset Management, 6, 74-91.

Bing, L., Akintoye, A., Edwards, P. J., \& Hardcastle, C. (2005). Critical success factors for PPP/ PFI projects in the UK construction industry. Construction Management and Economics, 23, 459-471.

Chan, A. P. C., Lam, P. T. I., Chan, D. W. M., Cheung, E., \& Ke, Y. J. (2010). Critical success factors for public-private partnerships: A Chinese perspective. Journal of Construction Engineering and Management, 136, 484-494.

Chen, F. (1999). Critical success factors for various strategies in the banking industry. International Journal of Bank Marketing, 17, 83-91.

Cheung, E., Chan, A. P. C., Lam, P. T. I., Chan, D. W. M., \& Ke, Y. J. (2012). A comparative study of critical success factors for public private partnerships (PPP) between Mainland China and Hong Kong special administrative region. Facilities, 30, 647-666.

Chou, J., \& Pramudawardhani, D. (2015). Cross-country comparisons of key drivers, critical success factors and risk allocation for public-private partnership projects. International Journal of Project Management, 33, 1136-1150.

Committee for Acceleration of Priority Infrastructure Delivery. (2017). Key improvements in infrastructure delivery in Indonesia. http://www.unescap.org/sites/default/ files/1708026_Manila\%20Presentation\%20Material_Key\%20Improvements\%20in\%20 Infrastructure $\% 20$ Delivery\%20in\%20Indonesia $\% 20-\% 20$ KPPIP.pdf

Delmon, J. (2011). Public-private partnership projects in infrastructure: An essential guide for policy makers. Cambridge University Press.

Dulaimi, M. F., Alhashemi, M., Ling, F. Y. Y., \& Kumaraswamy, M. (2010). The execution of public-private partnership projects in the UAE. Construction Management and Economics, $28,393-402$.

Engel, E., Ronald, D. F., \& Galetovic, A. (2014). The economics of public-private partnership: A basic guide. Cambridge University Press.

Flyvbjerg, B. (2017). The Oxford handbook of megaproject management. Oxford University Press.

Grimsey, D., \& Lewis, M. (2007). Public private partnerships: The worldwide revolution in infrastructure provision and project finance. Edward Elgar Publishing. 
Gupta, A., Gupta, M. C., \& Agrawal, R. (2013). Identification and ranking of critical success factors for BOT projects in India. Management Research Review, 36, 1040-1060.

Hodge, G. A., \& Greve, C. (2007). Public-private partnerships: An international performance review. Public Administration Review, 67, 545-558.

Hodge, G. A., \& Greve, C. (2017). On public-private partnership performance: A contemporary review. Public Works Management \& Policy, 22, 55-78.

Hodge, G. A., Greve, C., \& Biygautane, M. (2018). Do PPP's work? What and how have we been learning so far? Public Management Review, 20, 1105-1121.

Hurk, M. V. D., Brogaard, L., Lember, V., Petersen, O. H., \& Witz, P. (2016). National varieties of public-private partnerships (PPPs): A comparative analysis of PPP-supporting units in 19 European countries. Journal of Comparative Policy Analysis: Research and Practice, $18,1-20$.

Ismail, S. (2013). Critical success factors of public private partnership (PPP) implementation in Malaysia. Asia-Pacific Journal of Business Administration, 5, 6-19.

Jacobson, C., \& Choi, S. O. (2008). Success factors: Public works and public-private partnerships. International Journal of Public Sector Management, 21, 637-657.

Jefferies, M., Gameson, R., \& Rowlinson, S. (2002). Critical success factors of the BOOT procurement system: Reflections from the Stadium Australia case study. Engineering, Construction and Architectural Management, 9, 352-361.

Kavishe, N., \& Chileshe, N. (2018). Critical success factors in public-private partnerships (PPPs) on affordable housing schemes delivery in Tanzania: A qualitative study. Journal of Facilities Management, 17, 188-207.

Ke, Y., Wang, S. Q., \& Chan, A. P. C. (2013). Risk misallocation in public-private partnership projects in China. International Public Management Journal, 16, 438-460.

Ke, Y., Wang, S. Q., Chan, A. P. C., \& Cheung, E. (2009). Research trend of public-private partnership in construction journals. Journal of Construction Engineering and Management, 135, 1076-1086.

Ke, Y., Wang, S. Q., Chan, A. P. C., \& Lam, P. T. I. (2010). Preferred risk allocation in China's public-private partnership (PPP) projects. International Journal of Project Management, $28,482-492$.

Klijn, E. H., Edelenbos, J., \& Hughes, M. (2007). Public private partnership: A two-headed reform. A comparison of PPP in England and The Netherlands. In C. Pollitt, S. V. Thiel, \& V. Homburg (Eds.), New public management in Europe: Adaptation and alternatives (pp. 71-89). Palgrave Macmillan.

Klijn, E. H., \& Koppenjan, J. (2016). The impact of contract characteristics on the performance of public-private partnerships (PPPs). Public Money \& Management, 36, 455-462.

Klijn, E. H., \& Teisman, G. R. (2000). Governing public-private partnerships: Analysing and managing the processes and institutional characteristics of public-private partnerships. In S. Osborne (Ed.), Public-private partnerships: Theory and practice in international perspective (pp. 84-102). Routledge.

Klijn, E. H., \& Teisman, G. R. (2003). Institutional and strategic barriers to public-private partnership: An analysis of Dutch cases. Public Money \& Management, 23, 137-146.

Koppenjan, J. F. M. (2005). The formation of public-private partnerships: Lessons from nine transport infrastructure projects in The Netherlands. Public Administration, 83, 135-157.

Kumaraswamy, M. M., \& Morris, D. A. (2002). Build-operate-transfer-type procurement in Asian Mega-projects. Journal of Construction Engineering and Management, 128, 93-102. 
Kwak, Y. H. (2002). Analyzing Asian infrastructure development privatization market. Journal of Construction Engineering and Management, 128, 110-116.

Kwak, Y. H., Chih, Y., \& Ibbs, C. W. (2009). Towards a comprehensive understanding of public private partnerships for infrastructure development. California Management Review, $51,51-78$.

Kwofie, T. E., Afram, S., \& Botchway, E. (2016). A critical success model for PPP public housing delivery in Ghana. Built Environment Project and Asset Management, 6, 58-73.

Li, B., Akintoye, A., Edwards, P. J., \& Hardcastle, C. (2005). The allocation of risk in PPP/PFI construction projects in the UK. International Journal of Project Management, 23, 25-35.

Liu, J., Love, P. E. D., Smith, J., Regan, M., \& Davis, P. R. (2015). Life cycle critical success factors for public-private partnership infrastructure projects. Journal of Management, 31, Article 04014073.

Liu, T., Wang, Y., \& Wilkinson, S. (2016). Identifying critical factors affecting the effectiveness and efficiency of tendering processes in public-private partnerships (PPPs): A comparative analysis of Australia and China. International Journal of Project Management, 34, 701-716.

McKinsey Global Institute. (2016). Bridging global infrastructure gaps. https://www.un.org/ pga/71/wp-content/uploads/sites/40/2017/06/Bridging-Global-Infrastructure-Gaps-Fullreport-June-2016.pdf

Meng, X., Zhao, Q., \& Shen, Q. (2011). Critical success factors for transfer-operate-transfer urban water supply projects in China. Management in Engineering, 27, 243-251.

Ministry of National Development Planning. (2014). National Medium Term Development Plan (RPJMN) 2015-2019. http:/www.social-protection.org/gimi/gess/RessourcePDF. action?ressource.ressourceId $=50077$

Mohr, J., \& Spekman, R. (1994). Characteristics of partnership success: Partnership attributes, communication behavior, and conflict resolution techniques. Strategic Management Journal, 15, 135-152.

Ng, S. T., Wong, Y. M., \& Wong, J. M. (2012). Factors influencing the success of PPP at feasibility stage-A tripartite comparison study in Hong Kong. Habitat International, 36, 423-432.

Organisation for Economic Co-operation and Development. (2012). OECD reviews of regulatory reform Indonesia public-private partnership governance: Policy, process and structure.

Osei-Kyei, R., \& Chan, A. P. C. (2015). Review of studies on the critical success factors for public-private partnership (PPP) projects from 1990 to 2013. International Journal of Project Management, 33, 1335-1346.

Osei-Kyei, R., \& Chan, A. P. C. (2017a). Factors attracting private sector investments in publicprivate partnerships in developing countries: A survey of international experts. Journal of Financial Management of Property and Construction, 22, 92-111.

Osei-Kyei, R., \& Chan, A. P. C. (2017b). Implementing public-private partnership (PPP) policy for public construction projects in Ghana: Critical success factors and policy implications. International Journal of Construction Management, 17, 113-123.

Ozdoganm, I. D., \& Birgonul, M. T. (2000). A decision support framework for project sponsors in the planning stage of build-operate-transfer (BOT) projects. Construction Management and Economics, 18, 343-353. 
Pieters, I. J., Lotz, M., \& Brent, A. C. (2014). Investigating the financial close of projects within the South African renewable energy independent power producer procurement programme. South African Journal of Industrial Engineering, 25, 57-68.

PT Sarana Multi Infrastruktur. (2017). PPP projects in Indonesia: Issues and challenges. www. kdi.re.kr/common/seminar_down.jsp?fno $=5$ sDLotstSh858iD8fVLr7w\%3D\%3D\&fty $=\mathrm{IK}$ KLJlukyUcpG4EmUThiYg\%3D\%3D

Public-Private Infrastructure Advisory Facility. (2017). Toll-road PPPs: Identifying, mitigating and managing traffic risk. https://www.globalinfrafacility.org/sites/gif/files/Traffic\% $\% 20$ Risk.pdf

Qiao, L., Wang, S. Q., Tiong, R. L. K., \& Chan, T. S. (2001). Framework for critical success factors of BOT projects in China. The Journal of Structured Finance, 7, 53-61.

Rochart, J. F. (1979). Chief executives define their own data needs. Harvard Business Review, 57, 81-92.

Rochart, J. F. (1982). The changing role of the information system executive: A critical success factors perspective. Sloan Management Review, 24, 3-13.

Roumboutsos, A., \& Anagnostopoulos, K. P. (2008). Public-private partnership projects in Greece: Risk ranking and preferred risk allocation. Construction Management and Economics, 26, 751-763.

Sengupta, U. (2005). Government intervention and public-private partnerships in housing delivery in Kolkata. Habitat International, 30, 448-461.

Steijn, B., Klijn, E. H., \& Edelenbos, J. (2011). Public private partnerships: Added value by organizational form or management? Public Administration, 89, 1235-1252.

Tang, L. Y., \& Shen, Q. (2013). Factors affecting effectiveness and efficiency of analyzing stakeholders' needs at the briefing stage of public private partnership projects. International Journal of Project Management, 31, 513-521.

Tang, L. Y., Shen, Q., \& Cheng, E. W. L. (2010). A review of studies on public-private partnership projects in the construction industry. International Journal of Project Management, $28,683-694$.

Tiong, R. L. K. (1996). CSFs in competitive tendering and negotiation model for BOT projects. Journal of Construction Engineering and Management, 122, 205-211.

United Nations Economic and Social Commission for Asia and the Pacific. (2017). Infrastructure financing strategies for sustainable development in South-East Asia. http://www.unescap. $\mathrm{org} / \mathrm{sites} /$ default/files/Financing\%20Infrastructure\%20-\%20Sub-Regional_20170714.pdf

Verhoest, K., Petersen, O. H., Scherrer, W., \& Soecipto, R. M. (2015). How do governments support the development of public private partnerships? Measuring and comparing PPP governmental support in 20 European countries. Transport Reviews, 35, 118-139.

Wang, H., Liu, Y., Xiong, W., \& Zhu, D. (2019). Government support programs and private investments in PPP markets. International Public Management Journal, 22, 499-523.

Wang, Y. (2015). Evolution of public-private partnership models in American toll road development: Learning based on public institutions' risk management. International Journal of Project Management, 33, 684-696.

Weber, B., Staub-Bisang, M., \& Alfen, H. W. (2010). Infrastructure as an asset class: Investment strategy, sustainability, project finance and PPP. John Wiley.

Wibowo, A., \& Alfen, H. W. (2014). Identifying macro-environmental critical success factors and key areas for improvement to promote public-private partnerships in infrastructure: Indonesia's perspective. Engineering, Construction and Architectural Management, 21, 383-402. 
Wibowo, A., \& Alfen, H. W. (2015). Government-led critical success factors in PPP infrastructure development. Built Environment Project and Asset Management, 5, 121-134.

Wilson, D. I., Pelham, N., \& Duffield, C. F. (2010). A review of Australian PPP governance structures. Journal of Financial Management of Property and Construction, 15, 198-215.

Yescombe, E. R. (2007). Public-private partnerships: Principles of policy and finance. Butterworth-Heinemann.

Zhang, W. R., Wang, S. Q., Tiong, R. L. K., Ting, S. K., \& Ashley, D. (1998). Risk management of Shanghai's privately financed Yan'an Donglu tunnels. Engineering, Construction and Architectural Management, 5, 399-409.

Zhang, X. (2005a). Criteria for selecting the private-sector partner in public-private partnerships. Journal of Construction Engineering and Management, 131, 631-644.

Zhang, X. (2005b). Critical success factors for public-private partnerships in infrastructure development. Journal of Construction Engineering and Management, 131, 3-14.

Zhang, X. (2005c). Paving the way for public-private partnerships in infrastructure development. Journal of Construction Engineering and Management, 131, 71-80.

Zhao, Z., Zuo, J., Zillante, G., \& Wang, X. (2010). Critical success factors for BOT electric power projects in China: Thermal power versus wind power. Renewable Energy, 35, 12831291.

Zou, P. X. W., Wang, S., \& Fang, D. (2008). A life-cycle risk management framework for PPP infrastructure projects. Journal of Financial Management of Property and Construction, $13,123-142$.

\section{Author Biographies}

Kei Endo is assistant director at the Operations Strategy Department, Japan International Cooperation Agency (JICA), which provides financial and technical cooperation assistance to emerging countries. He is also a $\mathrm{PhD}$ candidate at Erasmus University Rotterdam. His research focuses on project and infrastructure finance in emerging countries.

Alberto Gianoli is an economist and management specialist based at the Institute for Housing and Urban Development Studies, Erasmus University Rotterdam, where he is the Head of Managing and Financing Sustainable Infrastructure. His main areas of expertise and interest include project and infrastructure finance and public-private partnerships.

Jurian Edelenbos is professor of interactive governance at the department of public administration and sociology, Erasmus University Rotterdam. He is also academic director of the Institute for Housing and Urban Development Studies, Erasmus University Rotterdam. He conducts multiple methods research in the fields of citizen participation, community-based initiatives, network management, boundary spanning, and trust. 